Goldschmidt 2021 Abstract

https://doi.org/10.7185/gold2021.6185

\section{Peridotite and pyroxenites from the mantle-wedge underneath the Northern Andes (Mercaderes area, Colombia)}

\author{
LUCA NOTINI ${ }^{1}$, ELISABETTA RAMPONE ${ }^{1}$, MARCO \\ SCAMBELLURI $^{2}$, ALBERTO ZANETTI ${ }^{3}$, FABIO FERRI ${ }^{4}$ \\ AND ANDRÉS RODRÍGUEZ-VARGAS ${ }^{5}$ \\ ${ }^{1}$ Università di Genova \\ ${ }^{2}$ Distav \\ ${ }^{3}$ IGG-CNR, Pavia \\ ${ }^{4}$ Università di Padova \\ ${ }^{5}$ Minerlab, Bogotá \\ Presenting Author: luca.notini@edu.unige.it
}

Peridotite and pyroxenites from the mantle-wedge underneath the Northern Andes (Mercaderes area, Colombia)

1. Notini ${ }^{1}$, E. Rampone ${ }^{1}$, M. Scambelluri ${ }^{1}$, A. Zanetti ${ }^{2}, F$. Ferri $^{3,4}$, A. Rodríguez-Vargas ${ }^{5}$

${ }^{1}$ Dipartimento di Scienze della Terra, dell'Ambiente e della Vita, Università di Genova, Italy

${ }^{2}$ IGG-CNR Pavia, Italy

${ }^{3}$ Dipartimento di Geoscienze, Università di Padova, Italy

${ }^{4}$ EIT Raw Materials, South Innovation Hub, Rome, Italy

${ }^{5}$ Minerlab, Bogotá, Colombia

In the Mercaderes - Rio Mayo area of Southern Colombia, the Pleistocenic Granatifera tuff contains peridotite and pyroxenite xenoliths offering a direct view of the supra-subduction mantle underneath the Northern Andes [1-2-3]. The xenoliths are heterogeneous and range from subordinated garnet peridotite to dominant garnet websterite and clinopyroxenite. A few xenoliths display slightly deformed granular structures (evident in garnet pyroxenite) that retain evidence of melt-rock interaction (e.g., anhedral interstitial garnet and pyroxene overgrowing coarse, deformed pyroxene grains). In most peridotite and pyroxenite xenoliths, the coarse granular assemblage is overprinted by porphyroclastic to mylonitic textures, characterized by ortho-, clinopyroxene and garnet porphyroclasts in a mylonitic orthopyroxene + clinopyroxene \pm olivine matrix.

Overall, mineral compositions define large intervals in terms of Mg-value (82-92) and $\mathrm{Na}$ contents in clinopyroxene $(0.70$ $1.60 \mathrm{wt} \%)$. On the other hand, within a single xenolith, the compositions of rock-forming minerals are very homogeneous without core-to-rim or porphyroclast-matrix variations. The Pressure-Temperature estimates from a selected number of peridotite and pyroxenite samples range between $1150^{\circ} \mathrm{C}-1250$ ${ }^{\circ} \mathrm{C}$ and 27-35 kbar (two pyroxene and garnet-pyroxene calibrations). The homogeneous porphyroclast and matrix compositions indicate the pervasive re-equilibration of all xenoliths during mylonitic deformation. Overall, the rock textures combined with mineral thermobarometry indicate that the Mercaderes xenoliths derive from a highly deformed mantle- wedge domain near the lithosphere-asthenosphere boundary, according to a recent geodynamic model of the area [4]. Despite the geodynamic location of the studied xenoliths, no modal metasomatism has been yet observed.

[1] Weber (1998), PhD Thesis. [2] Rodriguez-Vargas (2005), Lithos 82(3-4), 471-484. [3] Bloch (2017), Earth and Planetary Science Letters, 476, 47-58. [4] Wagner (2017), Geophysical Research Letters, 44(13), 6616-6623. 